\title{
Diversity and abundance of arbuscular fungi mycorrhizal (AMF) in rhizosphere Zea mays in tidal swamp
}

\author{
MARLIN SEFRILA ${ }^{1,2}$, MUNIF GHULAMAHDI ${ }^{1,3, \vartheta}$, PURWONO $^{1,3}$, MAYA MELATI $^{1,3}$, IRDIKA MANSUR $^{4}$ \\ ${ }^{1}$ Program of Agronomy and Horticulture, Graduate School, Institut Pertanian Bogor. Jl. Meranti, Kampus IPB Darmaga, Bogor 16680,West Java, \\ Indonesia. Tel.: +62-251-8629354, Fax.: +62-251-8629352, ^email: mghulamahdi@yahoo.com \\ ${ }^{2}$ Department of Agronomy, Faculty of Agriculture, Universitas Sriwijaya. Jl. Palembang-Prabumulih Km 32, Indralaya, Ogan Ilir 30662, South Sumatra, \\ Indonesia \\ ${ }^{3}$ Department of Agronomy and Horticulture, Faculty of Agriculture, Institut Pertanian Bogor. Jl. Meranti, Kampus IPB Darmaga, Bogor 16680, West \\ Java, Indonesia \\ ${ }^{4}$ Departement of Silviculture, Faculty of Forestry and Environment, Institut Pertanian Bogor. Jl. Lingkar Akademik, Kampus IPB Darmaga, Bogor \\ 16680, West Java, Indonesia
}

Manuscript received: 20 September 2021. Revision accepted: 26 October 2021.

\begin{abstract}
Sefrila M, Ghulamahdi M, Purwono Melati M, Mansur I. 2021. Diversity and abundance of arbuscular fungi mycorrhizal $(A M F)$ in rhizosphere Zea mays in tidal swamp. Biodiversitas 22: 5071-5076. This study aims to find out the diversity and dominance of AMF spores and look at the morphology of fungi mycorrhizal arbuscular fungi that exist in the rooting area of corn (Zea mays L.) crops in the tidal swamp. The study was conducted in September 2020. Soil sampling at the tidal swamp village of Mulyasari Tanjung Lago District, Banyuasin, South Sumatra, Indonesia randomly sampling the corn root zone method. The research stages are soil sampling, soil chemistry analysis, AMF isolation and trapping, and morphological identification of AMF spores. The results showed the number of spores found in soil samples in the corn crop rhizosphere before trapping was less when compared to after trapping. The spores' shape is round, oblong, and oval, with colors ranging from clear, yellow, to brown. AMF spores found come from 2 genera namely (Acaulospora scrobiculata, Acaulospora bireticulata, Acaulospora mellea, Acaulospora laevis) and Glomus (Glomus monosporum, Glomus constrictum, Glomus manihotis).
\end{abstract}

Keywords: AMF, isolation, tidal swamp

\section{INTRODUCTION}

Fungi mycorrhizal arbuscular is a Zygomycota mushroom of the endomycorrhiza type with a symbiotic relationship of mutualism with high levels of plant rooting. The plant supplies lipids and sugars to fungi, carbon sources for metabolic processes (Zhang et al. 2018). The existence of AMF in maintaining the stability of ecosystems naturally also in addition to being able to function as biofertilizers, bio-protection, and soil bioregulation, AMF acts as bio-fortification and phytoremediation, especially inland with high heavy metal content such as $\mathrm{Cu}, \mathrm{Fe}, \mathrm{Zn}, \mathrm{Co}$, and $\mathrm{Mn}$ (Ferrol et al. 2016). Mycorrhizal can be found in any land, including suboptimal land such as tidal land. The chemical constraints of tidal soils are the high pyrite content and soil salinity, and low soil fertility (Auditha et al. 2019).

Mulyasari Tanjung lago village is one of the transmigration areas in Banyuasin Regency of South Sumatra, Indonesia which is located in the tidal swamp (Septinar and Putri 2018). The tidal swamp is a sub-optimal land that is less productive but has the potential for the wide availability of land to be developed as agricultural land. AMF has excellent potential to recover less fertile land, where specific land conditions cause only a few types of commodities that can grow and provide optimal results. Crops can also develop in tidal swamps, including rice, corn, soybeans, green beans, peanuts, and sweet potatoes. AMF inoculant of corn (Zea mays L.) rhizosphere in saturated soil culture can increase nutrient uptake of $\mathrm{P}$ by plant, $\mathrm{P}$ levels of plants, the relative efficiency of inoculant, number of filling pods, and weight of soybean seeds Tanggamus varieties (Muis et al. 2016). AMF colonization, in general, shows positive results in crop production, mainly because AMF can provide the nutrients needed by host plants (Berruti et al. 2016).

AMF, in general, does not have a unique host plant and can be found in almost all types of soil; therefore, the number and variety are very diverse. Plant characteristics and environmental factors such as temperature, soil $\mathrm{pH}$, soil moisture, phosphorous content, and nitrogen also affect the presence of AMF. So that each ecosystem can contain AMF of the same or different type because the diversity and spread of AMF vary greatly due to changing environmental conditions. The amount of AMF spores on minimum soil is less when compared to the land processed intensively; the addition of chemical fertilizers will also affect the number of AMF spores (Sari et al. 2017). The abundance and diversity of AMF in 10 cornfields in northeast China found four ordo, nine families, and 12 genera. The quantity and variety of AMF are influenced by environmental factors, including soil organic $\mathrm{C}, \mathrm{N}, \mathrm{P}$, and pH (Zhu et al. 2020). 
The density, diversity, and spread of mycorrhizal vary widely, and this is due to different environmental factors in each place. Each mycorrhizal has other morphological properties because it is necessary to isolate to find out the type of AMF in the corn rhizosphere in a tidal land swamp. Each AMF can help promote plant growth and development, so the selection of AMF isolates suitable for the plant to be cultivated needs to be done. Efforts that can be made to obtain isolates from a particular ecosystem can be by conducting AMF exploration, identification of isolates from the field, and with AMF capture (Trapping). Taxonomic identification of AMF can be made traditionally based on the morphology of the spores; in addition, it can also make molecular identification of AMF by using $\mathrm{ADN}$ sequence data to find out the evolutionary relationships of AMF. Molecular identification of AMF can be made ADN sequence data has been successfully used to study the evolutionary relationships of AMF. Still, this method requires considerable expertise and a reasonably expensive cost, one of which is by biotyping MALDI TOFMS (Crossay et al. 2017).

This research aims to find out the number and diversity of AMF found in rhizosphere corn crops in the tidal swamp village of Mulyasari Tanjung Lago Banyuasin Regency of South Sumatra, Indonesia to provide information about the density and type of AMF in the rhizosphere of corn crops on tidal swamp Mulyasari Tanjung Lago Village Banyuasin Regency of South Sumatra, Indonesia.

\section{MATERIALS AND METHODS}

From September 2020 to March 2021, the study was conducted soil sampling at the tidal swamp village of Mulyasari Tanjung logo, Banyuasin Regency, South Sumatra, Indonesia which was planted with corn varieties Pioneer 27 aged 60 days after planting. Trapping AMF is carried out in greenhouse $F$ SOEMEO BIOTROP. In contrast, analysis of the type and number of AMF spores is carried out in the biosystem and landscape management laboratory of SEOMEO BIOTROP. The tools used are soil scopes, plastic bags, label paper, analytical scales, $425 \mu \mathrm{m}$ graded sieves, $212 \mu \mathrm{m}, 106 \mu \mathrm{m}$ and $63 \mu \mathrm{m}$, plastic cups, Petri cups, measuring cups, stirrers, plastic pipettes, $50 \mathrm{~mL}$ pot tubes, filter paper, binocular microscopes, toothpicks, spray gourds, centrifuge, $10 \mathrm{~cm}$ diameter plastic black pots and plastic funnels. The materials used are soil samples from the rhizosphere of the corn crop Pioneer variety 27 at tidal swamps, corn sprouts Pionier varieties 27 age 14 dap, aquades, glucose $60 \%$, polyvinyl alcohol-lactic acidglycerol (PVLG).

\section{Soil sampling}

Soil sampling is done at tidal breeds that have been planted with corn (Zea mays L.). The method used is the sampling method by taking 20 points around the corn root zone as much as $25 \mathrm{~g}$, with a depth of $0-20 \mathrm{~cm}$ and a diameter of $20 \mathrm{~cm}$, then the soil of the rhizosphere of each plant is put in a plastic bag and labeled. The ground example for nutrient analysis is a composite of 10 sampling points with a weight of $500 \mathrm{~g}$ each at a depth of $0-30 \mathrm{~cm}$ and put in a plastic bag. The sample soil will conduct the soil analysis in the Laboratory of the Department of Soil Science and Land Resources of the Faculty of Agriculture IPB, Bogor, Indonesia.

\section{Isolation and AMF trapping}

Isolation of AMF spores from soil samples is done by the wet strain pour method (Gerdemann and Nicolson 1963) and continued with a centrifuge (Brundrett et al. 1996). The AMF isolation process begins with a hardened soil sample, and then the soil is weighed as much as $10 \mathrm{~g}$ of $25 \mathrm{~g}$ of a soil sample, added $150 \mathrm{~mL}$ aquades, then stirred for 10 minutes until the soil grains are destroyed stand for 5 minutes. Soil samples that have been added aquades are further filtered using a multilevel sieve $(425 \mu \mathrm{m}, 212 \mu \mathrm{m}$, $106 \mu \mathrm{m}$, and $63 \mu \mathrm{m}$ respectively from top to bottom). Spores left behind in filters of $212 \mu \mathrm{m}, 106 \mu \mathrm{m}$ and $63 \mu \mathrm{m}$ are transferred into the test tube, respectively. Next added equates as much as $50 \mathrm{~mL}$ and glucose $60 \%(\mathrm{w} / \mathrm{v})$, then in a centrifuge at a speed of $3000 \mathrm{rpm}$ for 5 minutes. The centrifuge process will produce a layer in the middle of the tube between the layer of water and glucose, a collection of particles containing AMF spores. The coating is then taken and poured in a $63 \mu \mathrm{m}$ sieve, rinsed with running water to remove glucose. The remaining deposits in the sieve are poured into a petri dish and then viewed under a binocular microscope with a magnification of 100-400x. Trapping techniques used follow the method Brundrett et al. (1996) by using a culture pot with a diameter of $10 \mathrm{~cm}$. Planting media used in the form of soil samples as much as $50 \mathrm{~g}$ and zeolite rocks with a size of $1 \mathrm{~mm}$ as much as $150 \mathrm{~g}$. Previously used zeolite sterilized by washing first until the water is clear, soaked in boiling water, and then dried. The technique of filling the planting media in a culture pot is a culture pot filled with $100 \mathrm{~g}$ zeolite, then inserted soil from tidal land as much as $50 \mathrm{~g}$ and lastly covered with zeolite as much as $50 \mathrm{~g}$, so that the planting media is composed of zeolite-examples of soil-zeolite (Figure 1), corn is planted in each culture pot.

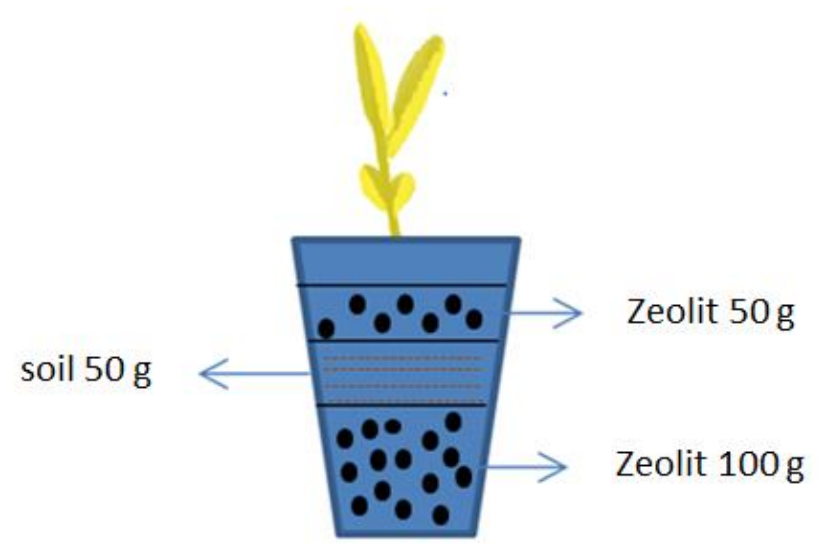

Figure 1. Zeolite media arrangement on pot trapping 
Culture pot distribution includes watering, fertilizing, and pest control manually. Fertilization using compound fertilizer (20-15-15) with a concentration of $1 \mathrm{~g}$ per liter of water is given once every week as much as $50 \mathrm{~mL}$ per pot of culture. After the plant is 90 days old, harvesting is done. The observed plagues are the density of AMF spores and the physical and chemical properties of the soil in soil samples. The thickness of spores is the number of spores per unit of soil weight (Koske 1987). The number of spores can be calculated by first extracting the spores, and then the extraction results are observed under a binocular microscope. The number of AMF calculated by hand tally counter is then observed also the color, shape, and size of FMA spores. Morphological identification of AMF spores is carried out up to the genus level about the criteria proposed by INVAM and some journal literature from the International Mycological Association (IMA) (Oehl et al. 2011). Data analysis is done using descriptive analysis through data tabulation.

\section{RESULTS AND DISCUSSIONS}

Soil isolation conducted on 20 soil samples taken from the corn crop rhizosphere at tidal swamp and downs in the exact location was obtained by several types of AMF spores. The number of AMF spores before trapping is less when compared to the number of spores after trapping in the same host plant, although the number of AMF spores found after trapping is still relatively low (Figure 2). The number of AMF spores from rhizosphere onion and chili plants in Siberia village ranges from 319-344 spores per 10 $\mathrm{g}$ of soil. Soils have a high AMF spore population; what if the density of the spores is 200 per $10 \mathrm{~g}$ of soil distribution and the number of AMF spores is primarily determined by the environmental conditions, physical and chemical properties of the soil (Sukmawaty et al. 2016). The population number and diversity of AMF types are very diverse. They are influenced by plant characteristics and environmental factors, including soil $\mathrm{pH}$, soil moisture, phosphorus, and nitrogen content, and heavy metal concentrations. The density of spores is in the range of 4.38-76.38 spores per $\mathrm{g}$ of soil. In total, 35 species of arbuscular mycorrhizal fungi from 10 genera have been identified. Glomus and Acaulospora are the dominant genera found at the root of tree plants in China's forests. Colonization of the highest arbuscular mycorrhizal fungi is found in the roots of Carya illinoensis (Wangenh.) $\mathrm{K}$. Koch, Zelkova serrata (Thunb.) Makinoz, Taxodium 'zhongshansha', Eucommia ulmoides Oliv., and Elaeagnus pungens Thunb., from $62.07 \%$ to $100 \%$ (Wang et al. 2019). The number of spores in Brachiaria precumbens rhizosphere is $8-25$ per $10 \mathrm{~g}$ soil sample and increases to an average of 49.6 spores per $10 \mathrm{~g}$ soil sample by trapping method (Suharno et al. 2017).

AMF spores found in the rhizosphere of corn plants have different spore shapes and colors (Table 1). AMF spores are grouped by color, body, and size obtained by two types of AMF genus before and after trapping, namely Acaulospora and Glomus. Types of AMF spores of the genus Acaulospora are Acaulospora scrobiculata Trappe, Acaulospora bireticulata F.M.Rothwell \& Trappe, Acaulospora mellea Spain \& N.C.Schenck, and Acaulospora laevis Gerd. \& Trappe, while from the genus Glomus namely Glomus monosporum Gerd. \& Trappe, Glomus constrictum Trappe, Glomus manihotis R.H.Howeler, Sieverd. \& N.C.Schenck (Figure 3).

The genus Acaulospora has the characteristics of spore walls consisting of 2-3 relatively thick layers, the color of the spores there is yellow to brownish with the shape of spores found round and oblong. The type of spores found from the Acaulospora tribal group is A. scrobiculata, which has a precise yellowish round shape with spores ranging from 80-160 $\mu \mathrm{m}$. Inoculation AMF Acaulospora sp. and compost $15 \%$ produces the highest biomass on teak seedlings in the soil media of former limestone mines (Prayudyaningsih and Sari 2016). The original Acaulospora also accelerated the adaptation process of Canavalia ensiformis inland with high nickel concentrations and was able to increase the number of lateral roots by $20.07-28.83 \%$ with a percentage of infected roots of 20.59-95.24\%; root length 11.26-31.76\%; root volume $20.51 \%$; dry root weight $5.73-16.77 \%$, and rootbud ratio 3.44-30.18\% (Akib et al. 2018). Acaulospora scrobiculata has spores round to somewhat round, light yellow to blackish yellow with relatively thick spore walls (Hasyiati et al. 2018). Acaulospora bireticulata has a yellowish brown color with a round to oval shape, a spore diameter of $29 \mu \mathrm{m}$ and a spore wall consisting of 3 layers (Chliyeh et al. 2016).

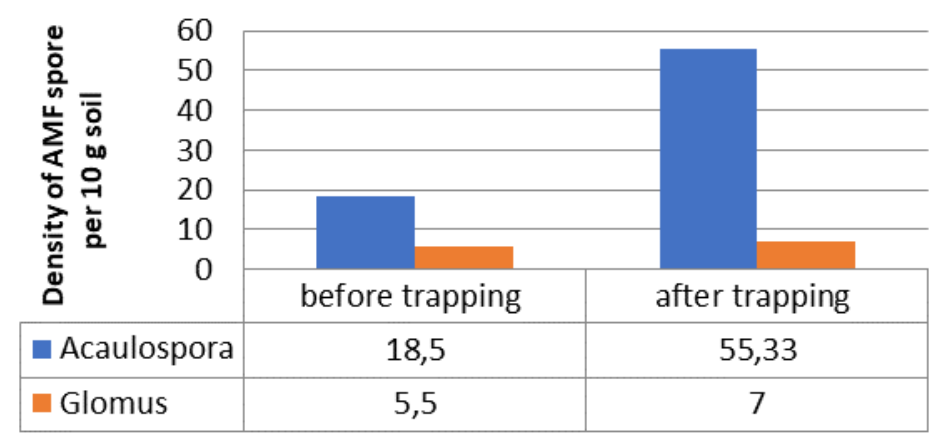

Figure 2. Types and abundance of AMF spores before trapping and after trapping on maize rhizosphere 

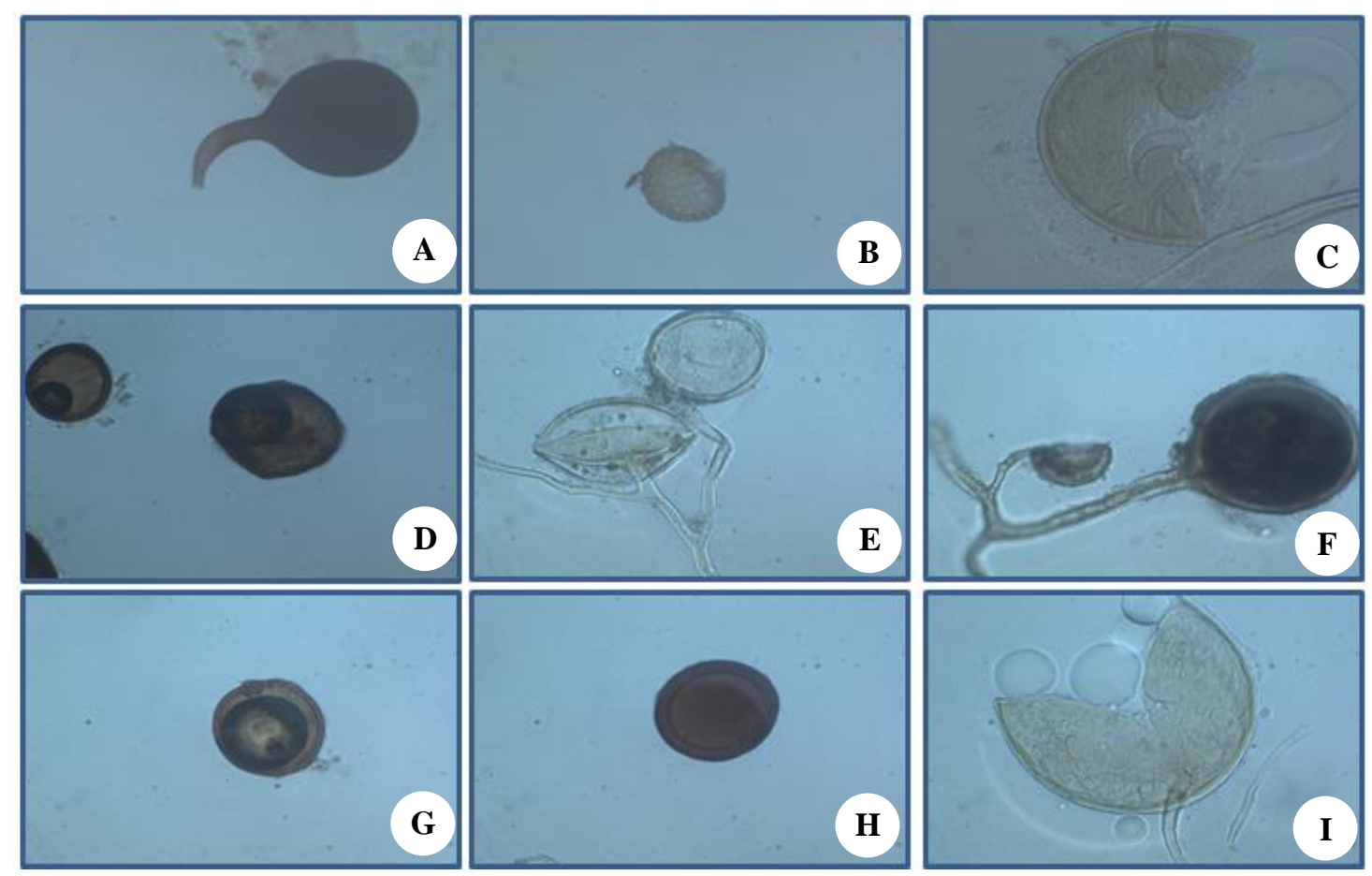

Figure 3. Several AMF spores found in the rhizosphere of corn plants in tidal land: A. Glomus constrictum; B. Acaulospora bireticulata; C, E, I. Glomus manihotis; D. Acaulospora scrobiculata; F. Acaulospora mellea; G. Glomus monosporum; H. Acaulospora laevis

The genus Glomus has a round-shaped feature, with some spore walls consisting of more than one layer. The color of the spores of the genus Glomus is clear, yellow, and brownish-yellow. Glomeraceae consists of $G$. constrictum, G. monosporum and G. manihotis. The genus Glomus belongs to the tribe Glomeraceae, wherein the rhizosphere cashews the most dominant group of AMF spores found is from the Glomus group compared to the AMF spores of the Racocetra, Entrophospora, Septoglomus, and Acaulospora groups. Electrophoresis results showed that the AMF ADN band reacted positively to the specific primary NS31 and AML2 with a band size of $560 \mathrm{bp}$, a fragmental measure for the Glomeromycota gene (Suada et al. 2018). Ambispora gerdemannii is a type of AMF of the phylum Glomeromycota, found in untreated vineyards with a limited amount of abundance (Oehl and Koch 2018). AMF spores are also found in many lowland rainforests that are always green, dry forests, and mountain forests (Marinho et al. 2018). Glomus spore development is from the end of hyphae that enlarges to the maximum size, forming spores (chlamydospores). Spores of the genus Glomus are derived from hyphae development so that hyphae will branch so that the spores can be found in a single form or loose aggregate (Hasyiati et al. 2018). The density of spores in the rhizosphere Retama raetam in Tunisia dominates the genus Glomus. There is a positive correlation between the phylogenetics of AMF, the chemical properties of the soil, and the rich diversity of AMF types (Mosbah et al. 2018).

The presence of this type of AMF is also determined by the season and age of the host plant; under unfavorable conditions will usually only be found in the form of spores, but after the situation returns to normal then the spores will germinate, which begins with the process of infection of the roots of the host plant. The abundance of AMF spores found in each rhizosphere of the host plant varies; this is due to many influencing factors such as nutrient content, $\mathrm{pH}$, total $\mathrm{P}$ content, $\mathrm{C}$-organic, and water content. The highest number of spore fungi, mycorrhizal arbuscular, are found in soil values, $\mathrm{pH}$, total $\mathrm{p}$, and low organic $\mathrm{C}$ (Yusriadi et al. 2018).

The results of the analysis of the physical and chemical properties of soil are factors that can affect the development and density of the number of AMF spores (Table 2). Based on the soil analysis results, the $\mathrm{pH} \mathrm{H}_{2} \mathrm{O}$ sample is relatively low, which is 3.78 or very sour so that it will affect the amount of AMF spore density. The results of the analysis of the physical and chemical properties of soil are factors that can affect the development and density of the number of AMF spores. Based on the soil analysis results, the $\mathrm{pH} \mathrm{H}_{2} \mathrm{O}$ sample is relatively low, which is 3.78 or very sour, so it will affect the amount of AMF spore density. Mycorrhizal is generally resistant to changes in soil $\mathrm{pH}$, so it will still find AMF in both alkaline and very acidic soils. Still, the amount depends on the adaptability of each AMF to be able to develop appropriately (Samsi et al. 2017). Compatibility tests showed that AMF could increase corn growth and had a noticeable effect on crop height, leaf area, and relative growth rate (Suharno et al. 2017). Soil microorganisms utilize Sub-optimal and infertile soils to aid plant growth by providing and absorbing plant nutrients, namely phosphorus $(\mathrm{P})$ and micro-elements. The presence of AMF found in the ground can help the plants continue to grow despite the poor soil conditions (Purwati et al. 2019). 
Table 1. Identification of some AMF spores found in corn plant rhizosphere before trapping

\begin{tabular}{|c|c|c|c|c|}
\hline \multirow{2}{*}{ AMF } & \multicolumn{3}{|c|}{ Spores main criteria for spores } & \multirow{2}{*}{ Source } \\
\hline & Color & Shape & Size & \\
\hline Acaulospora scrobiculata & $\begin{array}{l}\text { Clear-yellow } \\
\text { brownish }\end{array}$ & Round-oval & $\begin{array}{l}\text { Passed a } 106 \mathrm{~m} \text { sieve } \\
\text { (no. } 140 \text { mesh) }\end{array}$ & $\begin{array}{l}\text { (Sharma et al. 2009); (Sari et al. } \\
\text { 2017) }\end{array}$ \\
\hline Acaulospora bireticulata & Yellow & Round & $\begin{array}{l}\text { Passed } 106 \text { m (no. } 140 \\
\text { mesh) }\end{array}$ & $\begin{array}{l}\text { sieve INVAM 2021; (Lubna and } \\
\text { Pulate 2019); (Sari et al. 2017) }\end{array}$ \\
\hline Acaulospora mellea & Tawny & Unanimously & $\begin{array}{l}\text { Passedsieve } 106 \mu \mathrm{m} \\
\text { (no. } 140 \text { mesh) }\end{array}$ & (Al-Areqi et al. 2015) \\
\hline Acaulospora laevis & $\begin{array}{l}\text { Brownish } \\
\text { yellow }\end{array}$ & Round & $\begin{array}{l}\text { Passed a } 106 \mathrm{~m} \\
\text { (no. } 140 \text { mesh) sieve }\end{array}$ & (Sanchez-Lizarraga et al. 2017) \\
\hline $\begin{array}{l}\text { Glomus constrictum/ } \\
\text { Septoglomus constrictum }\end{array}$ & Blackish brown & Round & $\begin{array}{l}\text { Escapedsieve } 212 \mu \mathrm{m}(70 \\
\text { mesh) }\end{array}$ & INVAM 2021; (Semane et al. 2018) \\
\hline Glomus monosporum & Tawny & Round & $\begin{array}{l}\text { Lolossieve } 106 \mu \mathrm{m} \text { (no. } \\
140 \text { mesh) }\end{array}$ & (Gehlot and Singh 2015) \\
\hline Glomus manihotis & $\begin{array}{l}\text { Clear brownish } \\
\text {-yellow }\end{array}$ & Unanimously & $\begin{array}{l}\text { Passedsieve } 106 \mu \mathrm{m} \text { (no. } \\
140 \text { mesh) } 100-260 \mathrm{~m}\end{array}$ & INVAM 2021 \\
\hline
\end{tabular}

Table 2. Results of analysis of physical and chemical properties of soil samples in rhizosphere corn crops in tidal swamp

\begin{tabular}{llll}
\hline \multicolumn{1}{c}{ Analysis variables } & & Results & Criteria \\
\hline Extract 1:5 & $\mathrm{pH} \mathrm{H} 2 \mathrm{O}$ & 3.78 & Very acidic \\
& $\mathrm{pH} \mathrm{KCl}$ & 3.47 & Very acidic \\
Organic matter & $\mathrm{C} \mathrm{Walkley} \mathrm{\&} \mathrm{Black}$ & $5.49 \%$ & High \\
& $\mathrm{N} \mathrm{Kjedhal}$ & $0.24 \%$ & Medium \\
& $\mathrm{C} / \mathrm{N}$ & $22.88 \%$ & High \\
$\mathrm{P}_{2} \mathrm{O} 5$ & $\mathrm{HCl} \mathrm{25 \%}$ & $106.2 \mathrm{ppm}$ & Very high \\
& Bray 1 & $13.1 \mathrm{ppm}$ & High \\
CEC & & $34.80 \mathrm{cmol} / \mathrm{kg}$ & Height \\
Texture (pipette method) & Sand & $4.61 \%$ & \\
& Dust & $53.21 \%$ & $42.18 \%$ \\
\hline
\end{tabular}

Furthermore, the results of soil sample analysis obtained a high C-organic content of $5.49 \%$, which is likely to affect the number of AMF spores and the percentage of root infections by AMF. C-organic content is the content of organic matter in the soil that plants can directly absorb after undergoing the mineralization process. The most amount of AMF spores found in soil samples have a shallow organic $\mathrm{C}$ content, while the higher the value of organic $\mathrm{C}$, the fewer spores found are minimal (Samsi et al. 2017). High P-available content in the soil leads to the colonization of AMF in low plant roots, cassava planting inoculated with AMF with a total P content of $29.33 \mathrm{mg} /$ $100 \mathrm{~g}$ has an unlimited amount of spores 23 spores per $10 \mathrm{~g}$ of soil (Yusriadi et al. 2018).

Soil texture dominated by low or acidic fractions of dust and $\mathrm{pH}$ is a condition thought to be suitable for developing Acaulospora spores. Glomus has the most expansive distribution area, especially in the texture of clay and soil $\mathrm{pH}$ ranges from 5-7; in addition, Glomus is more resistant to soil copy, and Glomus type AMF spores have a massive number of species compared to other types of AMF (Asmarahman et al. 2018). The diversity and abundance of AMF spores obtained before and after trapping the corn crop rhizosphere are relatively low. It is thought to be influenced by low $\mathrm{pH}, \mathrm{C}$-Organic and high $\mathrm{P}$ content, and dusty clay texture also has to do with the value of CEC. The degree of colonization of arbuscular mycorrhizal fungi is significantly negatively correlated with the soil phosphorus content. In contrast, the colonization intensity of arbuscular mycorrhizal fungi is negatively correlated with groundwater content, total carbon, soil ph, and organic matter content (Wang et al. 2019). The AMF colonization rate in lowlands elevation plant rhizospheres showed the highest infection rate of $81.1 \%$, while the lowest infection rate occurred in plains areas at 64.4\% (Marizal et al. 2017).

This study concludes that the amount of spores found in soil samples in the corn crop rhizosphere before trapping is less when compared to after trapping. The spores' shape is round, oblong, and oval, with colors ranging from clear, yellow, to brown. AMF spores found are from two genera Acaulospora (A. scrobiculata, A. bireticulata, A. mellea, A. laevis) and Glomus (G. monosporum, G. constrictum, Glomus manihotis).

\section{ACKNOWLEDGEMENTS}

The authors would like to thank SEOMEO BIOTROP, and this research is also part of the Doctoral Dissertation (PDD) research funded under contract No. 1/E1/KP.PTNBH/2021 dated March 8, 2021. 


\section{REFERENCES}

Akib MA, Mustari K, Kuswinanti T, Syaiful SA. 2018. The effect of application Acaulospora sp. on the root growth of Canavalia ensiformis L. at Nickel post-mine land. Pak J Biotechnol 15 (2): 583 591.

Al-Areqi AHNA, Chliyeh M, Touati J, Outcoumit A, Sghir F, Ouazzani TA, Benkirane R, Douira A. 2015. Effect of endomycorrhizae on decline of the coffee plants (Coffea arabica) caused by Fusarium solani. IJAPBC 4 (2): 397-404.

Asmarahman C, Budi SW, Wahyudi I, Santoso E. 2018. Identification of potential microbes of arbuscular mycorrhizal fungi (AMF) in Pos Mining Land of PT. Holcim Indonesia Tbk, Cibinong, Bogor, West Java. J Nat Resour Environ Manag 8 (3): 279-285. DOI: 10.29244/jpsl.8.3.279-285.

Auditha JV, Budianta D, Setiawan D. 2019. Perubahan beberapa sifat kimia tanah lahan pasang surut akibat budidaya tanaman jagung (Zea mays L .). In: Herlinda S, editor. Prosiding Seminar Nasional Lahan Suboptimal 2019 "Smart Farming yang Berwawasan Lingkungan untuk Kesejahteraan Petani”. Palembang, 4-5 September 2019. [Indonesian]

Berruti A, Lumini E, Balestrini R, Bianciotto V. 2016. Arbuscular mycorrhizal fungi as natural biofertilizers: Let's benefit from pas successes. Front Microbiol 6 (JAN): 1-13. DOI: 10.3389/fmicb.2015.01559.

Brundrett M, Bougher N, Dell B, Grove T, Malajczuk N. 1996. Working with mycorrhizas in forestry and agriculture. Australian Centre for International Agricultural Research, Canberra.

Chliyeh M, Kachkouch W, Zouheir T, Touhami AQ, Abdelkarim FilaliMaltouf, Modafar C El, Moukhli A, Benkirane R, Douira A. 2016. Evolution of a composite endomycorrhizal inoculums in function of time in the level of the olive plants rhizosphere. Intl J Adv Pharm Biol Chem 5 (1): 1-14.

Crossay T, Antheaume C, Redecker D, Bon L, Chedri N, Richert C, Guentas L, Cavaloc Y, Amir H. 2017. New method for the identification of arbuscular mycorrhizal fungi by proteomic-based biotyping of spores using MALDI-TOF-MS. Sci Rep 7 (14306): 1-16. DOI: $10.1038 / \mathrm{s} 41598-017-14487-6$.

Ferrol N, Tamayo E, Vargas P. 2016. The heavy metal paradox in arbuscular mycorrhizas: from mechanisms to biotechnological applications. J Exp Bot 67 (22): 6253-6265. DOI: 10.1093/jxb/erw403.

Gehlot P, Singh J. 2015. Arbuscular mycorrhizal fungi, Glomus spp. Glomeromycetes), associated with drought tolerant plants of the Indian Thar desert. Austrian J Mycol 24: 15-22.

Gerdemann JW, Nicolson TH. 1963. Spores of mycorrhizal endogone species extracted from soil by wet sieving and decanting. Trans $\mathrm{Br}$ Mycol Soc 46 (2): 235-244. DOI: 10.1016/s0007-1536(63)80079-0.

Hasyiati R, Wulandari N, Haidilianda. 2018. Keanekaragaman fung mikoriza arbuskula (Fma) pada beberapa jenis pohon di Pegunungan Deudap Pulo Aceh Kabupaten Aceh Besar. Prosiding Biotik 6 (1) 496-509.

raniry.ac.id/index.php/PBiotik/article/view/4290 [10 092021 [Indonesian]

Koske RE. 1987. Distribution of VA mycorrhizal fungi along a latitudinal temperature gradient. Mycologia 79 (1): 55-68. DOI: $10.2307 / 3807744$

Lubna K, Pulate. 2019. Arbuscular mycorrhizal biodiversity associated with Citrus aurentifolia from Amravati region. Intl J Life Sci 7 (2): 229-235

Marinho F, Da Silva IR, Oehl F, Maia LC. 2018. Checklist of arbuscular mycorrhizal fungi in tropical forests. Sydowia 70: 107-127. DOI: 10.12905/0380.sydowia70-2018-0107.

Marizal S, Muzakir, Syariyah A. 2017. The diversity of arbuscular mycorrhiza fungus (AMF) indigenous in peanuts (Arachis hypogea $\mathrm{L}$ ) rhizosphere under different elevation. J Trop Soils 21 (2): 109-114. DOI: $10.5400 /$ jts.2016.v21i2.109-114.

Mosbah M, Philippe DL, Mohamed M. 2018. Molecular identification of arbuscular mycorrhizal fungal spores associated to the rhizosphere of Retama raetam in Tunisia. Soil Sci Plant Nutr 64 (3): 335-341. DOI: 10.1080/00380768.2018.1431012.

Muis R, Ghulamahdi M, Melati M, Purwono, Mansur I. 2016 Kompatibilitas fungi mikoriza arbuskular dengan tanaman kedelai pada budidaya jenuh air. Jurnal Penelitian Pertanian Tanaman Pangan
35 (3): 229-238. DOI: 10.21082/jpptp.v35n3.2016.p229-237. [Indonesian]

Oehl F, Koch B. 2018. Diversity of arbuscular mycorrhizal fungi in no-till and conventionally tilled vineyards. J Appl Bot Food Qual 91 (March): 56-60. DOI: 10.5073/JABFQ.2018.091.008.

Oehl F, Sieverding E, Palenzuela J, Ineichen K, Silva GA da. 2011. Advances in Glomeromycota taxonomy and classification. IMA Fungus 2 (2): 191-199. DOI: 10.5598/imafungus.2011.02.02.10.

Prayudyaningsih R, Sari R. 2016. The application of arbuscular mycorrhizal fungi (AMF) and compost to improve the growth of teak seedlings (Tectona grandis linn. f.) on limestone post-mining soil. Jurnal Penelitian Kehutanan Wallacea 5 (1): 37-46. DOI: 10.18330/jwallacea.2016.vol5iss1pp37-46. [Indonesian]

Purwati B, Budi SW, Wasis B. 2019. Diversity of arbuscular mycorrhizae fungi from rhizosphere of Daemonorops draco Blume in Jambi. Media Konservasi 24 (3): 261-268. DOI: 10.29244/medkon.24.3.261268.

Samsi N, Pata'dungan YS, Thaha AR. 2017. Isolasi dan identifikasi morfologi spora fungi mikoriza arbuskula pada daerah perakaran beberapa tanaman hortkultura di lahan pertanian Desa Sidera. [Doctoral Dissertation]. Tadulako University, Central Sulawesi. [Indonesian]

Sanchez-Lizarraga AL, Dendooven L, Marino-Marmolejo EN, DavilaVazquez G, Hernández-Cuevas L, Arenas-Montaño V, ContrerasRamos SM. 2017. Presence and diversity of arbuscular mycorrhizal fungi in soil regularly irrigated with vinasses. J Soil Sci Plant Nutr 17 (4): 1116-1129. DOI: 10.4067/S0718-95162017000400020.

Sari S, Kumastuti A, Indrawati W. 2017. Identifikasi fungi mikoriza arbuskular (Fma) tanaman leguminosa secara mikroskopis pada lahan olah tanah konservasi musim tanam ke 29. Jurnal Penelitian Pertanian Terapan 17 (1): 40-49. [Indonesian]

Semane F, Chliyeh M, Kachkouch W, Touati J, Selmaoui K, Touhami AO, Filali-Maltouf A, El Modafar C, Moukhli A, Benkirane R, Douira A. 2018. Follow-up of a composite endomycorrhizal inoculum in the rhizosphere of olive plants, analysis after 42 months of culture. Ann Res Rev Biol 22 (2): 1-18. DOI: 10.9734/arrb/2018/38604.

Septinar H, Putri MK. 2018. Pengelolaan tata air lahan pertanian rawa pasang surut sebagai upaya melestarikan lingkungan di Desa Mulya Sari Kecamatan Tanjung Lago Kabupaten Banyuasin. Media Komunikasi Geografi 19 (2): 187-193. DOI: 10.23887/mkg.v19i2.16499. [Indonesian]

Sharma S, Parkash V, Kaushish S, Aggarwal A. 2009. A monograph of Acaulospora spp. (Vam Fungi) in sunflower rhizosphere in Haryana, India. Helia 32 (50): 6976. DOI: 10.2298/HEL0950069S

Suada IK, Prima E, Sritamin M, Adiartayasa IW, Susrama IGK, Wirawan IGP. 2018. Isolation and identification of arbuscular mycorrhizal fungi (AMF) in cashew plant (Anacardium occindentale L.) in Datah village, Abang district of Karangasem regency. Intl J Biosci Biotechnol 5 (2): 168-175. DOI: 10.24843/IJBB.2018.v05.i02.p10.

Suharno, Soetarto ES, Sancayaningsih RP, Kasiamdari RS. 2017. Association of arbuscular mycorrhizal fungi (AMF) with Brachiaria precumbens (Poaceae) in tailing and its potential to increase the growth of maize (Zea mays). Biodiversitas 18 (1): 433-441. DOI: 10.13057/biodiv/d180157.

Sukmawaty E, Hafsan, Asriani. 2016. Identifikasi cendawan mikoriza arbuskula dari perakaran tanaman pertanian. Biogenesis 4 (1): 16-20. DOI: 10.24252/bio.v4i1.1115. [Indonesian]

Wang J, Wang GG, Zhang B, Yuan Z, Fu Z, Yuan Y, Zhu L, Ma S, Zhang J. 2019. Arbuscular mycorrhizal fungi associated with tree species in a planted forest of eastern China. Forests 10 (5): 1-14. DOI: 10.3390/f10050424

Yusriadi, Pata'dungan YS, Hasanah U. 2018. Kepadatan dan keragaman spora fungi mikoriza arbuskula pada daerah perakaran beberapa tanaman pangan di lahan pertanian Desa Sidera. Agroland: Jurnal Ilmu-Ilmu Pertanian 25 (1): 64-73. [Indonesian]

Zhang S, Lehmann A, Zheng W, You Z, Rillig MC. 2018. Arbuscular mycorrhizal fungi increase grain yields: A meta-analysis. New Phytol 222 (1): 543-555. DOI: 10.1111/nph.15570.

Zhu X, Yang W, Song F, Li X. 2020. Diversity and composition of arbuscular mycorrhizal fungal communities in the cropland black soils of China. Glob Ecol Conserv 22 (1): 1-4. DOI: 10.1016/j.gecco.2020.e00964 